\title{
Antitrust and Artificial Intelligence: A Research Agenda
}

\section{Nicolas Petit*}

Since last year, the hype around "Artificial Intelligence" ("AI") has reached the antitrust community. A common thread to the emerging literature on Antitrust and AI ("AAI") is to describe the increasing use of algorithms on markets as a game changer. ${ }^{1}$ In their page turner book Virtual Competition, Professors Ariel Ezrachi and Maurice Stucke prophesize the "end of competition as we know it", and advocate heightened government intervention.

The AAI literature makes three claims. First, algorithms will widen instances in which known forms of anticompetitive conduct occurs. The AAI scholarship conjectures that express and tacit collusion as well as almost perfect behavioral discrimination will be more common. Second, algorithmic markets will display new forms of anticompetitive conduct in non price dimensions like data capture, extraction and co-opetition (between "super-platforms" and applications developpers) which challenge established antitrust doctrine. Third, deception is a design feature of algorithmic markets. Behind the "façade" of competition, consumers are nudged in exploitative transactions. In a telling metaphor, Ezrachi and Stucke compare us to the main character in the movie the Truman show.

AAI literature is the closest ever our field came to science-fiction. Like science-fiction, it is a lot of fun. And like science-fiction, its scenarios unearth fascinating research hypotheses for antitrust experts. Five areas deserve attention. First, the AAI literature essentially focuses on the facilitating role of algorithms on anticompetitive conduct. Those findings must now be complemented by a symmetrical investigation of the destabilizing effect of algorithms on harm to competition. Take the tacit collusion scenarios. The AAI literature makes a convincing case that algorithms are a plus factor which renders tacit collusion more stable, durable and versatile by facilitating detection and retaliation at lower levels of market concentration. Yet, the reciprocal hypothesis that oligopolists in high frequency interaction may have stronger incentives to cheat is given shorter shrift. When transactions are customized - a feature of the digitalized economy - each bargain with a customer can be seen as a finite, one shot game which is incompatible with tacit collusion. Similarly, when personalized and dynamic pricing are combined, the range of price points over which oligopolists must coordinate is virtually infinite, because it is a function of the number of individual customers times the number of time units spent on digital markets. Last, when nonprice competition on privacy and behavioral discrimination are introduced, there is more "noise" in the market, and detecting an punishing deviations may be significantly more costly.

\footnotetext{
* Professor of Law, University of Liege (ULg) and Research Professor, University of South Australia (UniSA), senior Scholar, International Center for Law and Economics ("ICLE"). Comments can be sent at Nicolas.petit@ulg.ac.be

${ }^{1}$ A Ezrachi and ME Stucke. Virtual Competition: The Promise and Perils of the Algorithm-Driven Economy (2016). SK Mehra, 'Antitrust and the Robo-Seller: Competition in the Time of Algorithms' (2016) 100 Minn. L. Rev., 1323-1375. G Surblyte, 'Data-Driven Economy and Artificial Intelligence: Emerging Competition Law Issues' (2017) 67(3) WuW, 120-127. R. Calo, 'Digital Market Manipulation'(2014), George Washington Law Review 82, 995-1034.
} 
Second, we still lack a proper understanding of countervailing strategies. To date, much of the AAI's literature focuses on $\mathrm{B} 2 \mathrm{C}$ markets where sellers use algorithms to exploit boundedly rational consumers. But in B2B markets, sophisticated buyers may have ability and incentives to make or buy countermeasures that undermine the operation of sellers' algorithms. Personnally, I doubt that many car manufacturers will stay prey to input sellers' algorithms, even in the extreme scenario where the later are super-platforms like Google, Facebook or Apple. The dieselgate is a bitter reminder of the automotive industry's technological capabilities. And the fast development of the cybersecurity industry suggests a non trivial chance that we will witness the emergence of a market for countermeasure systems (data pertubation, masking and randomization sofware, for example). ${ }^{2}$

Third, the AAI literature generates predictions on the basis of fairly strict assumptions, and more work is needed to understand if they are robust to circumstances. Tacit collusion is conceivably easier if one postulates that rival oligopolists use similar or homogeneous algorithms. Yet, as soon as the analysis is conducted under the assumption of algorithmic heterogeneity, a larger range of competitive outcomes becomes plausible. It is indeed uncontroversial that tacit collusion is less easy when oligopolists display asymmetries in costs, investments, structure or market share, and we should attempt to understand the effects of algorithmic differentiation at preference specification (design) or construction (learning) stages. To put the point differently, because in the real world, algorithms are neither commodities - scientific progress in algorithm design is relentless - nor public goods - the EU search case against Google brings a powerful reminder - algorithmic asymetry should be baseline hypothesis for antitrust policy. The same applies to the assumption that profit-maximizing algorithms - unlike humans - do not fear detection and possible penalties. True that unlike humans, a computer cannot be incarcerated. But if we follow the assumption that an algorithm does not register losses, then there is no basis to consider that it can register the profits of anticompetitive activity. The point here is that a utilitarian algorithm is an agent that necessarily operates on behalf of someone else. And therefore a reasonable assumption is that a profit-maximizing pricing algorithm will specify a fiduciary duty towards its vicarious governors, which will integrate constraints like antitrust compliance.

Fourth, an area where additional research is needed is evidence. Much of the early AAI papers report perverse instantiations of algorithmic exploitation. An often-heard example is about the book "The Making of a Fly", which sold once for \$23 million on Amazon's platform. But one should not forget that customers happen to make bad deals on very competitive markets. And that circumstancial cases of consumer harm caused by pricing algorithms do not tell us much on whether market power is being exerted to an extent and intensity that deserves antitrust remediation. With this, it is unclear if the facts advanced in AAI literature denote " $a$ brief perturbation in competitive conditions" as Judge Posner once wrote, or whether they constitute emerging proof of a market failure worthy of agency interest. 3

\footnotetext{
${ }^{2}$ Ezrachi and Stucke only envision briefly « public countermeasures », and discard them as too slow to cope with fast moving markets.

3 See Dissent by Judge Posner in Parts \& Elec. Motors, Inc. v. Sterling Elec., Inc., 866 F.2d 228, 236 (CA7 1988). See also Dissent by Justice Scalia in Eastman Kodak v. Image Technical Servs. (90-1029), 504 U.S. 451 (1992).
} 
Last, but not least, the main hard question raised by AAI literature relates to the goals of antitrust. There remains a lot of ideological resistance in both the US and the EU to the idea that antitrust laws should address wealth transfers between sellers and buyers, and this could elevate an unsurmountable obstacle to the application of the competition rules to consumer exploitation through almost perfect behavioral discrimination and personal data extraction. Aware of that distributional controversy, Ezrachi and Stucke advance an additional - and profound - idea: virtual competition increases the "deadweight loss by increasing distrust". 4 Presenting the social costs of algorithmic exploitation in trust terms is appealing. Trust in strangers is a feature of modern economies. Third-party enforcement mechanisms like the courts system, regulation and antitrust laws create trust and promote exchange amongst aliens. 5 But is "trust" the core business of antitrust law? Taxation, war or corruption all reduce trust, and inflict a deadweight loss on society. Yet, few would advance the proposition that antitrust laws should be used to address such harms. ${ }^{6}$ In my view, the social costs of algorithmic exploitation can be searched closer to established antitrust theory. When algorithms absorb most or all consumer surplus in a relevant market, they create an income constraint on consumers, which shifts the demand curve inward on an indeterminate number of other markets. 7 This, in turn, reduces the sales opportunities of other producers, and shrinks a range of (ir-relevant) markets, which is a deadweight loss. From a policy perspective, this rationale could legitimize antitrust remediation against perfect behavioral discrimination (correcting for efficiencies), but would leave untouched personal data extraction, given the non rival and imperfectly appropriable nature of data (no income constraint).

Most of the abovementioned issues will need to be discussed, tested and resolved before the scenarios of AAI literature can be integrated in policy environments. To date, the EU policy makers have not yet envisioned algorithmic exploitation as an antitrust issue. This does not mean that we live in a regulatory void. Few, in our field, have realized that the EU is at the forefront of the discussion on the regulation of AIs. The new General Data Protection Regulation has introduced a right to object to " $a$ decision based solely on automated processing, including profiling, which produces legal effects". ${ }^{8}$ And last month, the European Parliament has adopted a wide ranging resolution on civil law rules on robotics. 9

\footnotetext{
4 And is thus a source of allocative inefficiency because "market economies rely on trust". See Ezrachi and Stucke, supra note 1 , at 242 and 243.

5 See P Seabright, The Company of Strangers, Princeton University Press (2010), 69.

6 With the possible exception of M. Pertschuk, former FTC official in the late 1970s. See WE Kovacic, 'Politics and partisanship in U.S. Federal Antitrust Enforcement' (2014) 79(2) Antitrust L.J., 687-711 and WJ Baer, 'At the Turning Point : The Commission in 1978' (1988) 7 J. public policy mark, 11-20.

7 See, for an early exposition, N Petit, 'Excessive Pricing: The Flaws of 'Tea Party' Competition Policy' (2011) 2(6) JECLaP, 519-520.

8 See Regulation (EU) 2016/679 of the European Parliament and of the Council of 27 April 2016 on the protection of natural persons with regard to the processing of personal data and on the free movement of such data, and repealing Directive 95/46/EC (General Data Protection Regulation), OJ L 119, 4 May 2016, 1-88, Article 22.

9 M Vestager, 'Algorithms and competition', Bundeskartellamt 18th Conference on Competition, Berlin, 16 March 2017, available at https://ec.europa.eu/commission/commissioners/20142019/vestager/announcements/bundeskartellamt-18th-conference-competition-berlin-16-march2017_en.
} 
But even more importantly, this does not imply that our antitrust police is passive or that "antritrust is dead" as Judge Posner wrily put it a week ago. ${ }^{10}$ In the EU, the legal doctrines of antitrust are more diverse than in the US. Think of fluid, though little applied, constructs like "collective dominance", "exploitative abuses" or even "concerted practices" 11 Moreover, the treshold level for remedial intervention is notably lower than in US antitrust law. Instead, the current observational strategy of the EU Commission on that front reflects a welcome commitment to evidence-based antitrust policy. In March, EU Competition Commissioner Vestager said that we should "keep a close eye on how algorithms are developing", and learn from early experiences. She added: "We certainly shouldn't panic about the way algorithms are affecting markets". Until the technology matures, and academic research improves, Ms. Vestager's humble policy position will preserve us from waging early wars at things that presently remain virtual market failures.

${ }^{10}$ See M-Lex Report, “'Antitrust is dead,' US appellate judge says of agency inaction”, Antitrust Law Spring Meeting 2017.

${ }_{11}$ The Court in Eturas showed that the concept of "concerted practice" could be adjusted to cover novel collusion scenarios like the outsourcing of pricing decisions to an upstream algorithmic platform. See Case C-74/14 "Eturas" UAB and Others $v$ Lietuvos Respublikos konkurencijos taryba, EU:C:2016:42. 